\title{
Autoantibodies against tyrosyl-tRNA synthetase and its separated domains at essential hypertension
}

\author{
M. Yu. Grom ${ }^{1}$, L. F. Yakovenko², V. M. Granich ${ }^{3}$, A. S. Dobrohod ${ }^{3}$, \\ O. O. Torbas ${ }^{3}$, G. D. Radchenko ${ }^{3}$, Yu. M. Sirenko ${ }^{3}$, L. L. Sidorik², A. I. Kornelyuk ${ }^{2}$ \\ ${ }^{1}$ Educational and Scientific Center "Institute of Biology" \\ Taras Shevchenko National University of Kyiv \\ 64/13, Volodymyrska Str., Kyiv, Ukraine, 01601 \\ 2 Institute of Molecular Biology and Genetics, NAS of Ukraine \\ 150, Akademika Zabolotnoho Str., Kyiv, Ukraine, 03680 \\ ${ }^{3}$ National Scientific Center "M. D. Strazhesko Institute of Cardiology, NAMS of Ukraine" \\ 5, Narodnogo Opolchennya Str., Kyiv, Ukraine, 03680 \\ grom.m.yu@gmail.com
}

In addition to the key role in biosynthesis some aminoacyl-tRNA synthetases provide non-canonical functions. Particularly, separated fragments of tyrosyl-tRNA synthetase (TyrRS) involved into angiogenesis and inflammation. Meanwhile, the vascular inflammation and endothelial dysfunction are central characteristics of the pathogenesis of essential hypertension (EH). The latest studies highlight a role of antibodies in physiopathology of EH. Aim. To investigate the full-length TyrRS and its domains as autoantigens in sera of the persons with $\mathrm{EH}(\mathrm{n}=25)$, the healthy individuals with family history of the pathology $(\mathrm{n}=12)$, and in the control group of healthy subjects $(n=32)$. Methods. The recombinant TyrRS and its separated domains coupled with Histags and generated by Escherichia coli were purified by chromatography on Ni-NTA-agarose. The levels of specific autoantibodies (aAbs) in sera of volunteers were measured by ELISA and confirmed in an immunoblotting assay. Results. Some subjects with elevated levels of aAbs against the full-length enzyme were detected in the cohort studies. $52 \%$ of the persons with EH as immunoreactive against miniTyrRS $(\mathrm{p}<<0.001)$ and $50 \%$ against CTD $(\mathrm{p}=0.002)$ were identified. In $50 \%$ of the healthy individuals with family history of $\mathrm{EH}(\mathrm{p}=0.037)$ the levels of anti-CTD aAbs were elevated. Conclusions. The increased levels of aAbs against miniTyrRS and CTD in sera of the persons with EH potentially may be used as a prognostic marker of the disease severity or therapy effectiveness. Moreover, the immunoreactivity of healthy individuals with family history of EH against CTD may be an early marker of hypertension.

Keyw or d s: aminoacyl-tRNA synthetases, miniTyrRS, cytokine, endothelial dysfunction, cardiovascular disease, prognostic marker.

\section{Introduction}

Tyrosyl-tRNA synthetase (TyrRS) is one of 20 conservative ancient enzymes that are critical at the initial stage of protein synthesis. The aminoacylation reaction, catalyzed by aminoacyl-tRNA synthetases, attaches each amino acid to its cognate tRNA $[1,2]$. In addition to the aminoacylation, tRNA synthetases perform other non-canonical functions due to the interac- tions with various cellular partners [3]. New missions can be associated with their cytoplasmic forms as well as with nuclear and secreted extracellular forms that affect the signaling, immune response, and pathways of the cardiovascular development $[4,5]$. Considering the functional versatility of ARSs, their expanded functions and expression may be associated with the pathology of various human diseases [6]. These enzymes are implicated into the neuronal diseases [7-9], tumorogene-

(C) 2015 M. Yu. Grom et al.; Published by the Institute of Molecular Biology and Genetics, NAS of Ukraine on behalf of Biopolymers and Cell. This is an Open Access article distributed under the terms of the Creative Commons Attribution License (http://creativecommons.org/licenses/by/4.0/), which permits unrestricted reuse, distribution, and reproduction in any medium, provided the original work is properly cited 
sis, [10], autoimmune diseases, namely, antisynthetases syndrom [11-13], and heart failure [14].

The native mammalian TyrRS is a procytokine [15]. Under apoptotic conditions, it can be secreted and split by leukocyte elastase into two fragments with distinct cytokine properties $[16,17]$. The N-terminal catalytic fragment (miniTyrRS) with a Glu-Leu-Arg (ELR) cytokine motif is a potent promoter of the angiogenesis [18] and polymorphonuclear leukocytes recruitment $[19,20]$. The C-terminal domain (CTD) has a high sequence similarity to the mature form of the pro-inflammatory cytokine-like protein known as human Endothelial-Monocyte-Activating Polypeptide (EMAP II) [21] endowed with angiogenic properties $[22,23]$.

Considering that the functional diversity of ARSs is often associated with pathological conditions, and that the separated domains of TyrRS are actively involved in the angiogenesis, we inferred a role of TyrRS in the cardiovascular diseases. Moreover, taking into account the capacity of the enzyme fragments to endotheliocytes recruitment [24-27], probably TyrRS is pathologically associated with essential hypertension (EH).

The latest studies are focused on the activities of TyrRS domains in the treatment of cardiovascular diseases (CVD) [28-30], but they do not consider the importance of specific autoantibodies (aAbs) against TyrRS and its natural fragments. Meanwhile, the role of antibodies in the pathogenesis of CVD, including $\mathrm{EH}$, is highlighted [31]. Therefore, the investigation of aAbs against TyrRS and its natural fragments can improve our understanding of an importance of the enzyme and its separated domains in health and pathologies in general, EH in particular. The purpose of this study was to identify the autoantibodies against TyrRS and its individual modules in sera of the persons with $\mathrm{EH}$, the healthy individuals with family history of $\mathrm{EH}$, and the normal healthy subjects in a control group.

\section{Materials and Methods}

\section{Patients and Sera}

128 persons with EH were examined (35.3 \% females and $64.7 \%$ males; mean \pm SD ages $48.4 \pm 27,6$ ). All of them had high blood pressure from 7 to 20 years. Serum samples were selected from 25 well-charac- terized persons with $\mathrm{EH}$ and with or without target organ damage, 12 healthy individuals with family history of EH, and 32 healthy volunteers. The males were recruited into all of the cohort studies in a higher proportion. This research was conducted in compliance with the declaration of Helsinki and was approved by the local ethics committee in the National Scientific Center «M.D. Strazhesko Institute of Cardiology» of NAMS of Ukraine. All subjects were informed of the study purposes, and their informed consents were obtained.

\section{Production and purification of TyrRS and its separated domains}

Generation of the recombinant full-length His-TyrRS (528 aa), His-miniTyrRS (362 aa), and His-CTD (166 aa) of Bos taurus has been performed according to our previous report [14]. The use of the bovine proteins is valid because of a high identity to the human TyrRS and its natural fragments $(\approx 95 \%)$. The constructed plasmid vectors designated as pET-30a-TyrRS, pET30a-miniTyrRS, and pET-30a-His-CTD were transformed into E. coli BL21 (DE3) pLysE cells (Novagen, Madison, WI) grown in Lysogeny broth (LB) at $37^{\circ} \mathrm{C}$ to optical density (OD) of $0.7-0.9(600 \mathrm{~nm})$. The expression of recombinant proteins with $1 \mathrm{mM}$ isopropyl- $\beta$-D(2)-thiogalactopyranoside(IPTG,Fermentas, Cambridge, United Kingdom) was induced for $4 \mathrm{~h}$. Affinity purification of the recombinant proteins from the cultural media using nickelnitriloacetic acid (NiNTA resin, Thermo Scientific, USA) was carried out according to the manufacturer's recommendations. The purity of His-TyrRS, His-mini-TyrRS, and HisCTD was confirmed by sodium dodecyl sulfate-polyacrylamide gel electrophoresis (SDS-PAGE) using a mixture of marker proteins (Fermentas, Lithuania).

\section{ELISA assay}

Specific binding of serum IgG aAbs to the recombinant enzyme or its separated domains was analyzed using direct solidphase ELISA. TyrRS, miniTyrRS, or CTD $(1 \mu \mathrm{g} /$ well) in a phosphate-buffered saline (PBS, pH 7.4) were incubated in 96-well polystyrene plates. Then the plates were washed ten times with PBS containing $0.1 \%$ Tween-20 (PBS-T), and, in order to block non-specific binding, the samples 
were incubated for $1 \mathrm{~h}$ at $37^{\circ} \mathrm{C}$ with $100 \mu \mathrm{l}$ of PBS-T added to each well. Subsequently, the wells loaded with $1: 50$ diluted aliquots of sera were incubated for $18 \mathrm{~h}$ at $4{ }^{\circ} \mathrm{C}$ after washing with PBS-T. $100 \mu \mathrm{l}$ of horseradish peroxidase (HRP)-conjugated goat antihuman IgG antibodies (Sigma, USA) were added to each well and incubated for $1 \mathrm{~h}$ at $37^{\circ} \mathrm{C}$. The plates were washed again with PBS-T, then with the substrate solution, containing $0.02 \% \mathrm{H}_{2} \mathrm{O}_{2}, 0.1 \mathrm{M}$ citrate-phosphate buffer ( $\mathrm{pH} 5.8$ ), and $0.5 \mathrm{mg} / \mathrm{mL} 2,2$ 'azino-bis(3-ethylbenzothiazoline-6-sulphonic acid) sodium salt (Sigma, USA), was added to each well. After $20 \mathrm{~min}$ of incubation at $37^{\circ} \mathrm{C}$, the absorbance was measured at $405 \mathrm{~nm}$ in ELISA reader. PBS, preimmune serum of rabbit, and secondary antibodies served as negative controls. The sera from immunized by the full-length TyrRS rabbits were used as positive controls. For each sample, the OD of the uncoated well was subtracted from the OD of the coated well and then subjected to the data analysis. The $\mathrm{OD}$ values greater than the mean $+2 \mathrm{SD}$ values of the normal controls were considered as positive.

\section{Western blot analysis of recombinant peptides}

The bacterially expressed His-TyrRS, His-miniTyrRS, and His-CTD recombinant proteins were boiled, resolved by $12 \%$ SDS-PAGE, and electrotransferred to the nitrocellulose membrane (Amersham Bioscience, Germany). The membrane was divided into strips and blocked by $5 \%$ non-fat milk in PBS-T for $1 \mathrm{~h}$ at room temperature followed by a triple wash with PBS containing $0.1 \%$ Tween-20. The strips with PBS-T, immunized by TyrRS rabbit serum ( $1: 75)$, and sera of the control healthy individuals, or the healthy subjects with family history of CVD, or the patients with $\mathrm{EH}(1: 100)$ were incubated for $18 \mathrm{~h}$ at $4{ }^{\circ} \mathrm{C}$. The peroxidase-conjugated secondary antibodies (Sigma, USA) to the strips after washing and incubated were added for $1 \mathrm{~h}$ at a room temperature. The strips were washed, and the immunoreactivity was detected by ChemiDoc System (Bio-Rad Laboratories, USA).

\section{Statistical analysis}

All statistical analyses were performed using the Statistica software, version 7.0. Differences in non-par-

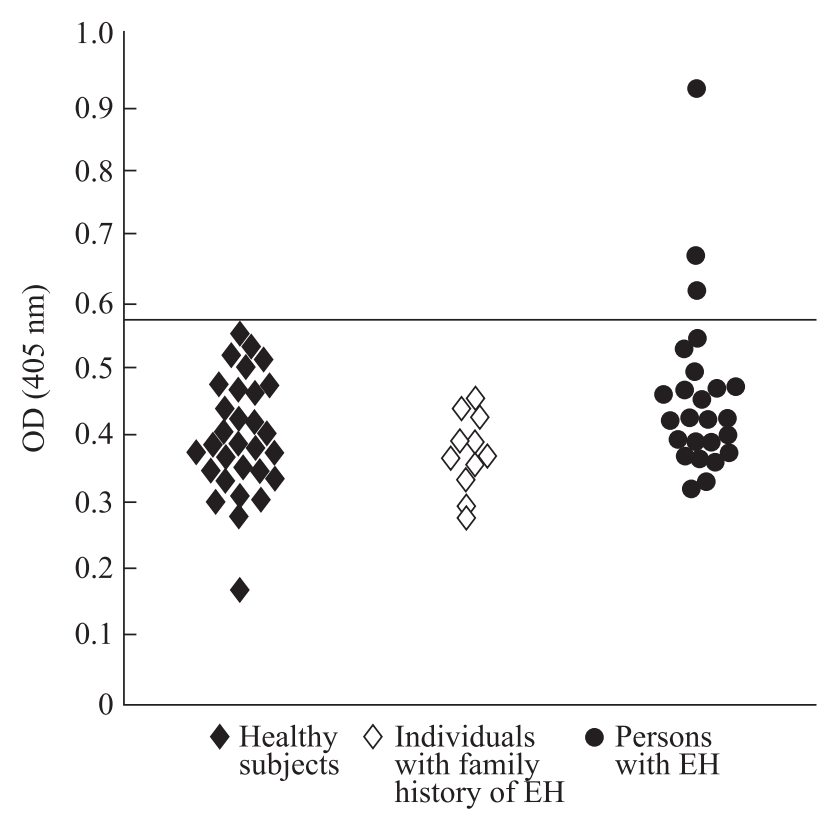

Fig. 1. Anti-TyrRS aAb levels in sera from persons with EH, healthy individuals with family history of $\mathrm{EH}$ and healthy controls shown as OD values. The line shows the cut-off value and means median $+2 \mathrm{SD}$ values for the healthy controls

ametric data were tested by the Mann-Whitney test. A P-value less than 0.05 was considered as statistically significant.

\section{Results}

\section{Production and characterization of recombinant TyrRS, miniTyrRS, and CTD}

To generate the recombinant full-length TyrRS, miniTyrRS, and CTD, we expressed them in the E. coli BL21 (DE3) pLysE cells using the pET-30a expression system and His-tag sequence in order to facilitate the purification of the recombinant proteins. After induction with IPTG we observed high levels of the HisTyrRS, His-miniTyrRS, and His-CTD expression in bacterial cells. Then recombinant proteins were purified on Ni-NTA agarose under denaturing conditions. The required purity (more than $95 \%$ ) of the proteins was confirmed by SDS-PAGE (data not shown).

Detection of anti-TyrRS aAbs, anti-mini-TyrRS, and anti-CTD by ELISA

The presence of anti-CTD, anti-mini-TyrRS, and antiTyrRS aAbs in the serum samples of the persons with $\mathrm{EH}$, 

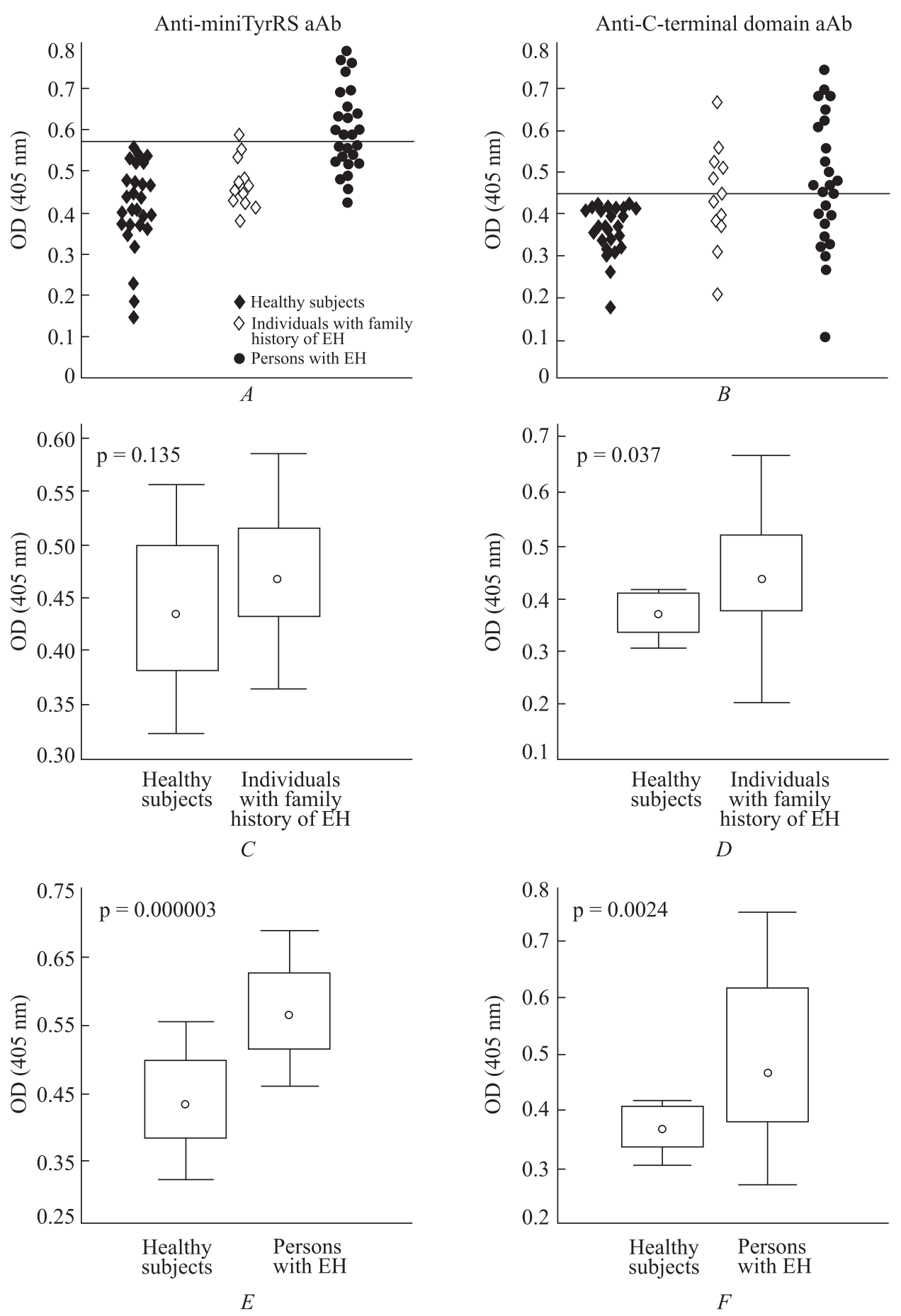

Fig. 2. Anti-mini-TyrRS $(A, C, E)$ and anti-CTD $(B, D, F)$ aAb levels in sera from persons with EH, healthy individuals wit family history of $\mathrm{EH}$ and healthy controls shown as OD values. The lines $(A, B)$ show the cut-off values and mean median $+2 \mathrm{SD}$ values for the healthy controls. Data $(D-F)$ are presented as box plots, where the boxes represent the $25^{\text {th }}$ to $75^{\text {th }}$ percentiles, the points within the boxes represent the median, and the lines outside the boxes represent the minimum and maximum values. Differences were analyzed by the Mann-Whitney U-test 
the healthy individuals with family history of $\mathrm{EH}$, and the normal controls was assessed by ELISA. The serum samples with $\mathrm{OD}$ values greater than the mean $+2 \mathrm{SD}$ values of the controls were considered as positive.

Anti-TyrRS (6.2\%), anti-miniTyrRS (15.6\%), and anti-CTD (24\%) aAbs were detected in serum samples of the healthy volunteers (data not shown).

Anti-TyrRS positive sera in $12 \%$ (3 of 25 ) of the persons with EH were observed (Fig. 1). The elevated levels of anti-miniTyrRS antidobies were detected in $52 \%$ (13 of 25$)$ of the persons with EH (Fig. 2, A). Anti-CTD positive sera were shown in $60 \%$ (15 of 25 ) of the persons with $\mathrm{EH}$ and $50 \%$ (6 of 12) of the individuals with family history of EH (Fig. 2, B). The serum anti-miniTyrRS concentrations were significantly higher in the persons with EH compared with those in the Ab-negative normal healthy volunteers $(\mathrm{p}<0.001)$. The serum levels of anti-CTD aAbs were elevated not only among the persons with EH ( $p=0.002)$, but also among the healthy individuals with family history of the pathology $(p=0.037)$.

Detection of anti-TyrRS, anti-mini-TyrRS, and anti-CTD aAbs by Western blotting

The ELISA representative serum samples (positive, poorly and moderate reactive) of each group were subsequently confirmed by Western blotting against the full-length TyrRS (Fig. 3, A) and its natural fragments (Fig. 3, B).

\section{Discussion and Conclusion}

A lot of studies postulate a role of autoantibodies in the pathogenesis of hypertension [32]. For several decades it was known that EH is associated with the elevated serum levels of IgG and IgM autoantibodies $[33,34]$. They can be involved into pathogenic reactions by binding to antigens expressed on the surface of endogenous cells, that leads to the destruction of cells via complement- or leukocyte-dependent interactions (type II hypersensitivity reaction) [35]. aAbs may form «immune complexes», that can be deposited in various tissues and cause the local inflammatory responses (type III hypersensitivity) [36]. They also can act as non-immunogenic agonists to the receptors (so-called «type V hypersensitivity»).
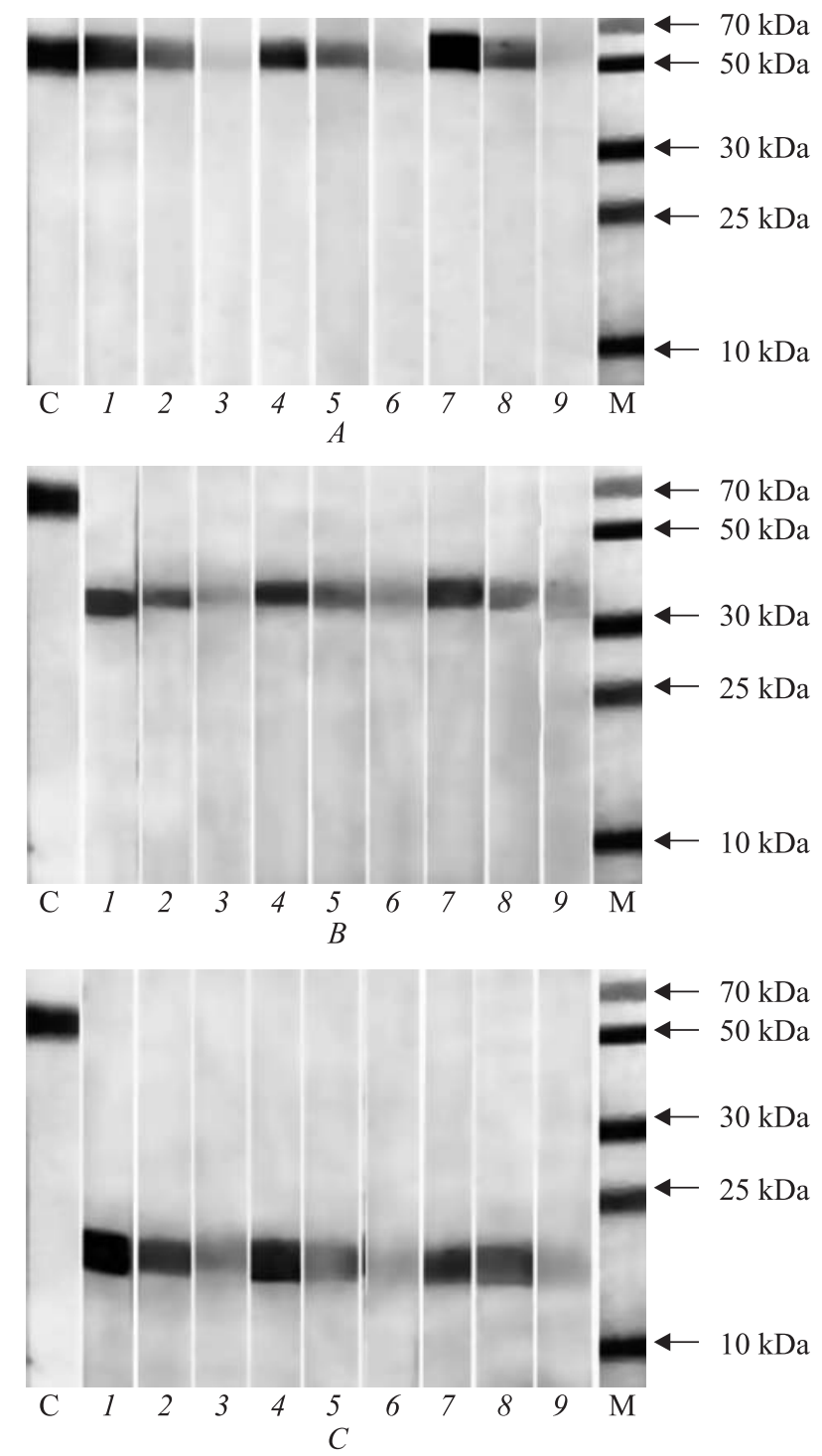

Fig. 3. Immunoreactivity of healthy subjects, individuals with family history of $\mathrm{EH}$, and persons with $\mathrm{EH}$ against TyrRS (40 $\mu \mathrm{g}$ for each protein) $(A)$, miniTyrRS $(B)$, and CTD $(C)$, obtained by Western blotting. Lines 1-3 represent the high, moderate, and low reactive sera of healthy volunteers against relevant protein according to ELISA; lines 4-6, by analogy, for individuals with family history of $\mathrm{EH}$; lines 7-9 for persons with hypertension. C is control line, incubated with serum of rabbit immunized by full-length TyrRS; M is protein MW marker

The numerous studies demonstrate the importance of autoantibodies against theangiotensin II type-1 receptors, [37, 38], alpha-1 adrenergic receptors [39], beta-1 adrenergic receptors [40], L-type voltage gated 
calcium channels [41], and heat shock proteins 70 and 60 [42-44] in the hypertension pathogenesis. The role of TyrRS and its natural fragments as well as autoantibodies against them in EH remains unknown.

$\mathrm{EH}$ is a multifactorial disease with indefinite etiology, its pathogenesis is clearly associated with the development of vascular endothelial dysfunction, characterized by pro-trombotic, pro-inflammatory and pro-constrictive vessel status [45]. Meanwhile, the endotheliocytes recruitment and the pro-inflammatory effects are the key properties of both distinct domains of TyrRS. [5, 17]. Considering all these facts, the involvement of natural fragments of the enzyme into pathogenesis of $\mathrm{EH}$ is quite possible.

This is the first investigation of the serum immunoreactivity of the persons with $\mathrm{EH}$, the healthy individuals with family history of $\mathrm{EH}$, and the healthy subjects against TyrRS and its separated domains. The study demonstrates the presence of persons with elevated levels of autoantibodies against the fulllength enzyme, miniTyrRS, and CTD in the normal healthy cohort. Such kind of immunoreactivity can be stipulated by some undetected inflammatory process that resulted in the secretion of TyrRS or the appearance of the full-length protein in the intercellular space due to apoptosis. Our data demonstrate the significant immunoreactivity against mini-TyrRS (52\%) and CTD (60 \%) among the persons with EH. Surprisingly, we found out the increased levels of autoantibodies against CTD in sera of $50 \%$ of the healthy individuals with family history of the pathology.

Difference in the values of aAbs against the fulllength enzyme and its natural fragments can be explained by the potential existence of the epitopes which are responsible for the cytokine activities and are sequestered in a native form by each other. The regions of cytokine activity - ELR on miniTyrRS and heptapeptide (Arg13-Thr19) on the N-terminus of CTD - in the full-length TyrRS have «face-toface» orientation, conditioned by the electrostatic interactions [46]. Under the apoptotic conditions, specifically inflammation, the native enzyme is secreted into intercellular space and can be cleaved by a extracellular protease such as leukocyte elastase. Moreover, the regions of cytokine activity can be un- masked in a cell via tRNA connection [46]. As a result, both sequences providing the cytokine activity, become available and two distinct fragments obtain new cytokine functions [16]. It seems absolutely logically to assume normally hidden sequences to be extremely immunogenic. The immunoreactivity of the persons with $\mathrm{EH}$ as well as of the individuals with family history of pathology suggests the presence of natural fragments of TyrRS, the formation of which is possible in terms of inflammation [17], known to be a component of the EH pathogenesis.

Earlier we have demonstrated the TyrRS and its separated domains as autoantigens in heart failure caused by the dilated cardiomyopathy, myocarditis and ischemic heart disease [14]. The highest immunoreactivity for the full-length enzyme and the lowest for CTD were revealed. According to our recent findings in sera of the patients with hypertension the highest levels of aAbs were found against the CTD and the lowest against the full-length enzyme. The data comparison suggests potential involvement of aAbs against CTD and miniTyrRS into the $\mathrm{EH}$ pathogenesis.

A practical significance of TyrRS and its separated domains is a «double-edged weapon». On the one hand, TyrRS is one of eight aminoacyl-tRNA synthetases involved into the antisynthetase syndrome [12], its mutant form occurs in Charcot-Marie-Tooth hereditary neuropathy [47]. On the other hand, miniTyrRs is a potential drug in the myocardial ischemia treatment [30]. Its particular role also was demonstrated in the platelet recovery in the patients suffering from the life-threatening thrombocytopenia or the bone marrow failure [28]. For recovery of cardiac function after myocardial infarction [29] CTD can be applied as an antiangiogenic stimulus [27].

However, the influence of aAbs on TyrRS and its separated domains in the disease pathogenesis as well as in the treatment strategies remains to be elucidated. Potentially, the elevated levels of autoantibodies against mini-TyrRS and CTD in sera of the persons with EH may be used as prognostic markers of the EH severity or the therapy effectiveness. Moreover, the immunoreactivity of healthy individuals with family history of EH against CTD may be an early marker of hypertension. 
Autoantibodies against tyrosyl-tRNA synthetase and its separated domains at essential hypertension

\section{Declaration of Interest}

The authors report no conflicts of interest. The authors alone are responsible for the content and writing of the paper.

\section{REFERENCES}

1. Mirande M. Aminoacyl-tRNA synthetase family from prokaryotes and eukaryotes: structural domains and their implications. Prog Nucleic Acid Res Mol Biol. 1991;40:95-142.

2. Kornelyuk AI. Structural and functional investigation of mammalian tyrosyl-tRNA synthetase. Biopolym Cell. 1998; 14(4): 349-59.

3. Guo M, Yang XL, Schimmel P. New functions of aminoacyl-tRNA synthetases beyond translation. Nat Rev Mol Cell Biol. 2010;11(9):668-74.

4. Sampath P, Mazumder B, Seshadri V, Gerber CA, Chavatte L, Kinter M, Ting SM, Dignam JD, Kim S, Driscoll DM, Fox PL. Noncanonical function of glutamyl-prolyl-tRNA synthetase: genespecific silencing of translation. Cell. 2004;119(2):195-208.

5. Greenberg Y, King M, Kiosses WB, Ewalt K, Yang X, Schimmel P, Reader JS, Tzima E. The novel fragment of tyrosyl tRNA synthetase, mini-TyrRS, is secreted to induce an angiogenic response in endothelial cells. FASEB J. 2008;22(5): 1597-605.

6. Park SG, Schimmel P, Kim S. Aminoacyl tRNA synthetases and their connections to disease. Proc Natl Acad Sci U S A. 2008;105(32):11043-9.

7. Nangle LA, Zhang W, Xie W, Yang XL, Schimmel P. Charcot-Marie-Tooth disease-associated mutant tRNA synthetases linked to altered dimer interface and neurite distribution defect. Proc Natl Acad Sci U S A. 2007;104(27):11239-44.

8. Kunst CB, Mezey E, Brownstein MJ, Patterson D. Mutations in SOD1 associated with amyotrophic lateral sclerosis cause novel protein interactions. Nat Genet. 1997;15(1):91-4.

9. Scheper GC, van der Klok T, van Andel RJ, van Berkel CG, Sissler M, Smet J, Muravina TI, Serkov SV, Uziel G, Bugiani M, Schiffmann R, Krägeloh-Mann I, Smeitink JA, Florentz C, Van Coster R, Pronk JC, van der Knaap MS. Mitochondrial aspartyl-tRNA synthetase deficiency causes leukoencephalopathy with brain stem and spinal cord involvement and lactate elevation. Nat Genet. 2007;39(4):534-9.

10. Won Lee S, Sun Kang Y, Kim S. Multifunctional proteins in tumorigenesis: aminoacyl-tRNA synthetases and translational components. Curr Proteomics. 2006;3(4):233-47.

11. Howard OM, Dong HF, Yang D, Raben N, Nagaraju K, Rosen A, Casciola-Rosen L, Härtlein M, Kron M, Yang D, Yiadom K, Dwivedi S, Plotz PH, Oppenheim JJ. Histidyl-tRNA synthetase and asparaginyl-tRNA synthetase, autoantigens in myositis, activate chemokine receptors on $\mathrm{T}$ lymphocytes and immature dendritic cells. J Exp Med. 2002; 196(6):781-91.

12. Mahler M, Miller FW, Fritzler MJ. Idiopathic inflammatory myopathies and the anti-synthetase syndrome: a comprehensive review. Autoimmun Rev. 2014;13(4-5):367-71.
13. Jura M, Rychlewski L, Barciszewski J. Comprehensive insight into human aminoacyl-tRNA synthetases as autoantigens in idiopathic inflammatory myopathies. Crit Rev Immunol. 2007;27(6):559-72.

14. Kondratiuk IuIu, Sidorik LL, Bobyk VI, Ryabenko DV, Kornelyuk AI. Identification of autoantibodies to tyrosil-tRNA synthetase in heart disfunctions. Biopolym Cell. 2010; 26 (5): 373-7.

15. Korneliuk AI, Kurochkin IV, Matsuka GKh. [Tyrosyl-tRNA synthetase from the bovine liver. Isolation and physico-chemical properties]. Mol Biol (Mosk). 1988;22(1):176-86.

16. Wakasugi K, Schimmel P. Two distinct cytokines released from a human aminoacyl-tRNA synthetase. Science. 1999; 284 5411):147-51.

17. Wakasugi K, Schimmel P. Highly differentiated motifs responsible for two cytokine activities of a split human tRNA synthetase. J Biol Chem. 1999;274(33):23155-9.

18. Belperio JA, Keane MP, Arenberg DA, Addison CL, Ehlert JE, Burdick MD, Strieter RM. CXC chemokines in angiogenesis. J Leukoc Biol. 2000;68(1):1-8.

19. Dean RA, Cox JH, Bellac CL, Doucet A, Starr AE, Overall CM. Macrophage-specific metalloelastase (MMP-12) truncates and inactivates ELR + CXC chemokines and generates CCL2, -7, -8, and -13 antagonists: potential role of the macrophage in terminating polymorphonuclear leukocyte influx. Blood. 2008;112(8):3455-64.

20. Wakasugi K, Slike BM, Hood J, Ewalt KL, Cheresh DA, Schimmel P. Induction of angiogenesis by a fragment of human tyrosyl-tRNA synthetase. J Biol Chem. 2002;277(23): 20124-6.

21. Levanets OV, Naidenov VG, Odynets KA, Woodmaska MI, Matsuka GKh, Kornelyuk AI. Homology of C-terminal noncatalytic domain of mammalian tyrosyl-tRNA synthetase with cylokine EMAP II and non-catalytic domains of methionyl- and phenylalanyl-tRNA synthetases. Biopolym Cell. 1997; 13(6): 474-8.

22. Kornelyuk AI, Tas M. PR, Dubrovsky AL, Murray JC. Cyokine activity of the non-catalytic EMAP-2-like domain of mammalian tyrosyl-tRNA synthetase. Biopolym Cell. 1999; 15(2):168-72.

23. Dubrovsky AL, Brown Jn, Kornelyuk AI, Murray JC, Matsu$k a G K h$. Bacterial expression of full-length and truncated forms of cytokine EMAP-2 and cytokine-like domain of mammalian tyrosyl-tRNA synthetase. Biopolym Cell. 2000; 16(3): 229-35.

24. Cheng G, Zhang H, Yang X, Tzima E, Ewalt KL, Schimmel P, Faber JE. Effect of mini-tyrosyl-tRNA synthetase on ischemic angiogenesis, leukocyte recruitment, and vascular permeability. Am J Physiol Regul Integr Comp Physiol. 2008; 295(4):R1138-46.

25. Zeng R, Chen YC, Zeng Z, Liu WQ, Jiang XF, Liu R, Qiang O, Li X. Effect of mini-tyrosyl-tRNA synthetase/mini-tryptophanyl-tRNA synthetase on ischemic angiogenesis in rats: proliferation and migration of endothelial cells. Heart Vessels. 2011; 26(1):69-80. 
26. Zeng R, Chen YC, Zeng Z, Liu XX, Liu R, Qiang O, Li X. Inhibition of mini-TyrRS-induced angiogenesis response in endothelial cells by VE-cadherin-dependent mini-TrpRS. Heart Vessels. 2012;27(2):193-201.

27. Ivakhno SS, Kornelyuk AI. Cytokine-like activities of some aminoacyl-tRNA synthetases and auxiliary p43 cofactor of aminoacylation reaction and their role in oncogenesis. Exp Oncol. 2004;26(4):250-5.

28. Ling Z, Yanling Z, Zhe F, Kui C, Xiushi Z, Min Y, Wei M. Recombinant human tyrosyl-tRNA synthetase, a novel thrombopoietic agent. Eur J Pharmacol. 2014;738:293-300.

29. McCormick ME, Rojas M, Moser-Katz T, Tzima E, Reader JS. Natural aminoacyl tRNA synthetase fragment enhances cardiac function after myocardial infarction. PLoS One. 2014;9(10):e109325.

30. Zeng R, Chen YC, Zeng Z, Liu WQ, Liu XX, Liu R, Qiang $\mathrm{O}$, Li X. Different angiogenesis effect of mini-TyrRS/miniTrpRS by systemic administration of modified siRNAs in rats with acute myocardial infarction. Heart Vessels. 2010; 25(4):324-32.

31. Chan CT, Lieu M, Toh BH, Kyaw TS, Bobik A, Sobey CG, Drummond GR. Antibodies in the pathogenesis of hypertension. Biomed Res Int. 2014;2014:504045.

32. Kondratiuk YuYu, Babaryk MA, and Kornelyuk OI. Bacterial expression optimization of mammalian tyrosyl-tRNA synthetase on strain Escherichia coli BL21 (DE3) pLysE cultivation. Mikrobiol Biotekhnol. 2009; 4(8):6-12.

33. Suryaprabha P, Padma T, Rao UB. Increased serum IgG levels in essential hypertension. Immunol Lett. 1984;8(3): 143-5.

34. Ebringer A, Doyle AE. Raised serum IgG levels in hypertension. Br Med J. 1970;2(5702):146-8.

35. Gehrs BC, Friedberg RC. Autoimmune hemolytic anemia. Am J Hematol. 2002;69(4):258-71.

36. Gross WL, Trabandt A, Reinhold-Keller E. Diagnosis and evaluation of vasculitis. Rheumatology (Oxford). 2000;39(3): 245-52.

37. Silva-Filho JL, Souza MC, Henriques Md, Morrot A, Savino W, Nunes MP, Caruso-Neves C, Pinheiro AA. AT1 receptormediated angiotensin II activation and chemotaxis of T lymphocytes. Mol Immunol. 2011;48(15-16):1835-43.

38. Zhou CC, Irani RA, Dai Y, Blackwell SC, Hicks MJ, Ramin SM, Kellems RE, Xia Y. Autoantibody-mediated IL-6dependent endothelin-1 elevation underlies pathogenesis in a mouse model of preeclampsia. J Immunol. 2011;186(10): 6024-34.

39. Piascik MT, Perez DM. Alpha1-adrenergic receptors: new insights and directions. J Pharmacol Exp Ther. 2001;298(2): 403-10.

40. Jahns R, Boivin V, Hein L, Triebel S, Angermann CE, Ertl G, Lohse MJ. Direct evidence for a beta 1-adrenergic receptor-directed autoimmune attack as a cause of idiopathic dilated cardiomyopathy. J Clin Invest. 2004;113 (10):1419-29.
41. Catterall WA. Voltage-gated calcium channels. Cold Spring Harb Perspect Biol. 2011;3(8):a003947.

42. Liao DF, Jin ZG, Baas AS, Daum G, Gygi SP, Aebersold R, Berk BC. Purification and identification of secreted oxidative stress-induced factors from vascular smooth muscle cells. J Biol Chem. 2000;275(1):189-96.

43. Pockley AG, De Faire U, Kiessling R, Lemne C, Thulin T, Frostegård J. Circulating heat shock protein and heat shock protein antibody levels in established hypertension. J Hypertens. 2002;20(9):1815-20.

44. Pockley AG, Wu R, Lemne C, Kiessling R, de Faire U, Frostegård J. Circulating heat shock protein 60 is associated with early cardiovascular disease. Hypertension. 2000;36(2): 303-7.

45. Dharmashankar K, Widlansky ME. Vascular endothelial function and hypertension: insights and directions. Curr Hypertens Rep. 2010;12(6):448-55.

46. Yang X-L, Liu J, Skene RJ, McRee DE, Schimmel P. Crystal structure of an EMAP-II-like cytokine released from a human tRNA synthetase. Helv Chim Acta. 2003;86(4):1246-57

47. Ermanoska B, Motley WW, Leitão-Gonçalves R, Asselbergh B, Lee LH, De Rijk P, Sleegers K, Ooms T, Godenschwege TA, Timmerman V, Fischbeck KH, Jordanova A. CMT-associated mutations in glycyl- and tyrosyl-tRNA synthetases exhibit similar pattern of toxicity and share common genetic modifiers in Drosophila. Neurobiol Dis. 2014;68:180-9.

\section{Аутоантитіла проти тирозил-тРНК синтетази та її окремих доменів при гіпертонічній хворобі}

М. Ю. Гром, Л. Ф. Яковенко, В. М. Граніч, Г. С. Доброход, О. О. Торбас, Г. Д. Радченко, Ю. М. Сиренко, Л. Л. Сидорик, О. І. Корнелюк

Окрім ключової ролі у біосинтезі білка певні аміноацилтРНК синтетази виконують також неканонічні функції. Зокрема окремі домени тирозил-тРНК синтетази залучені до ангіогенезу та запальних реакцій. Тим часом, судинні запалення і дисфункція ендотелію є центральними характеристиками патогенезу гіпертонічної хвороби (ГБ). Останні дослідження підкреслюють роль антитіл в патофізіології ГБ. Мета. Дослідити повнорозмірну TyrRS i ïi окремі домени як аутоантигени в сироватках осіб з ГБ (n=25), у здорових осіб з сімейною історією патології $(\mathrm{n}=12)$, і в контрольній групі здорових осіб $(\mathrm{n}=32)$. Методи. Рекомбінантна TyrRS i ïi окремі домени, пов'язані з Ніs-тегами, експресувалися в клітинах E.coli, та очищалися хроматографією на NiNTA-агарозе. Рівні специфічних аутоантитіл (aAbs) в сироватці добровольців були виміряні методом ІФА та підтверджені в імуноблотингу. Результати.Некоторие пацієнти 3 підвищеним рівнем aAbs проти повнорозмірного ферменту були виявлені в когортних дослідженнях. 52 \% осіб з ГБ були ідентифіковані як імунореактивні проти miniTyrRS (p $<0,001)$ і $50 \%$ проти CTD $(\mathrm{p}=0,002)$. У $50 \%$ здорових осіб 
3 сімейною історією ГБ ( $\mathrm{p}=0,037)$ рівні анти-CTD aAbs були підвищені. Висновки. Збільшення рівнів aAbs проти тіniTyrRS i CTD у сироватці осіб з ГБ потенційно може бути використане як прогностичний маркер ступеня тяжкості захворювання та ефективності терапії. Крім того, імунореактивність проти CTD здорових людей 3 сімейною історією ГБ може бути раннім маркером гіпертонії.

К л юч о в і с с о в а: аміноацил-тРНК синтетази, mini-TyrRS, цитокін, ендотеліальна дисфункція, серцевосудинні захворювання, прогностичний маркер.

\section{Аутоантитела против тирозил-тРНК синтетазы и ее отдельных доменов при гипертонической болезни}

М. Ю. Гром, Л. Ф. Яковенко, В. Н. Гранич, А. С. Доброход, Е. А. Торбас, А. Д. Радченко, Ю. М. Сиренко, Л. Л. Сидорик, А. И. Корнелюк

Кроме ключевой роли в процессе биосинтеза белка ряд аминоацил-тРНК синтетаз также исполняют, так называемые, неканонические функции. В частности, отдельные домены тирозилтРНК синтетазы вовлечены в ангиогенез и воспалительные реакции. Между тем, сосудистой воспаление и дисфункция эндотелия являются центральными характеристиками патогенеза гипертонической болезни (ГБ). Последние исследования подчеркивают роль антител в патофизиологии ГБ.
Цель. Исследовать полноразмерную TyrRS и ее отдельные домены как аутоантигены в сыворотках лиц с ГБ $(\mathrm{n}=25)$, у здоровых лиц с семейной историей патологии (n=12), и в контрольной группе здоровых лиц $(\mathrm{n}=32)$. Методы. Рекомбинантная TyrRS и ее отдельные домены, связанные с Hisтегами и экспрессированные в E. coli, очищали хроматографией на Ni-NTA-агарозе. Уровни специфических аутоантител (aAbs) в сыворотке добровольцев были измерены методом ИФА и подтверждены в иммуноблоттинге. Результаты. Некоторые пациенты с повышенным уровнем aAbs против полноразмерного фермента были обнаружены в когортных исследованиях. 52 \% лиц с ГБ были идентифицированы как иммунореактивные против miniTyrRS (p < 0,001) и 50 \% против CTD $(\mathrm{p}=0,002)$. У 50 \% здоровых лиц с семейной историей ГБ $(\mathrm{p}=0,037)$ уровни анти-CTD aAbs были повышены. Выводы. Увеличение уровней aAbs против miniTyrRS и CTD в сыворотке у лиц с ГБ потенциально может быть использовано в качестве прогностического маркера степени тяжести заболевания и эффективности терапии. Кроме того, иммунореактивность против CTD здоровых людей с семейной историей ГБ может быть ранним маркером гипертонии.

Кл юч е в ы е сл о в а: аминоацил-тРНК синтетазы, mini-Tyr $\mathrm{RS}$, цитокин, дисфункция эндотелия, сердечнососудистые заболевания, прогностический маркер

Received 20.05.15 